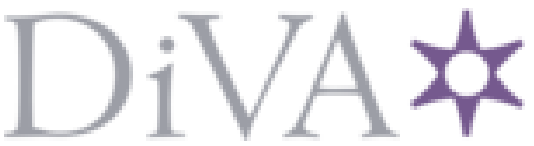

http://www.diva-portal.org

\title{
Postprint
}

This is the accepted version of a chapter published in Demography at the edge: remote human populations in developed nations.

Citation for the original published chapter:

Schmallegger, D., Harwood, S., Cerveny, L., Müller, D K. (2011)

Tourist populations and local capital

In: Dean Carson, Rasmus Ole Rasmussen, Prescott Ensign, Lee Huskey, Andrew Taylor

(ed.), Demography at the edge: remote human populations in developed nations (pp. 271-288). Farnham: Ashgate

N.B. When citing this work, cite the original published chapter.

Permanent link to this version:

http://urn.kb.se/resolve?urn=urn:nbn:se:umu:diva-41250 


\section{Tourist Populations and Local Capital}

\section{Doris Schmallegger, Sharon Harwood, Lee Cerveny, Dieter Müller Introduction}

One of the main challenges for remote communities is managing the limited human resources to generate local capital and restrict population decline. Attracting and retaining permanent resident populations in remote resource dependent settlements is challenging, particularly in times of economic restructuring and declining employment in resource extractive industries (see, for example, Halseth and Sullivan, 2003; Randall and Ironside, 1996; Bradbury and St-Martin, 1983). As a result, many remote communities become reliant on temporary or semi migrants to maintain services and stimulate local development. Tourists, as a short-term form of temporary migrants (Williams and Hall, 2000), are an important population source for remote areas. The apparent potential of tourism to stimulate local economic development and compensate for declines in traditional resource industries has been long recognised by government and economic development agencies (Hall and Boyd, 2005). Despite an increasing interest in adopting tourism as an economic 'saviour' for fragile remote communities, the impacts that various short-term tourist populations have on local resident populations, and the contributions that they can make to the development of local capital, are not well understood.

This chapter analyses three common, yet intrinsically different, types of tourist markets in remote regions in respect to their impacts on local communities and contributions to local capital. These include: short-term sightseeing tourists, activity based special interest tourists, and second home tourists. The chapter reports on three case studies conducted in desert Australia, Southeast Alaska and northern Sweden. It examines the unique characteristics of the three tourist populations and the type of tourism development that has emerged in the case study regions. The discussion then focuses on how the various 
forms of tourism development, in conjunction with the specific characteristics of their tourist populations, have impacted on a variety of factors that contribute to local capital. These include physical infrastructure, investment and ownership structures, local labour structures, knowledge and skills, or social capital. The results suggest that less transient and volatile tourist markets may provide stable opportunities that stimulate and enhance local capital development for remote communities. Conversely, targeting short-term mass tourism markets tend to create local economies that are dependent upon external capital, provide limited opportunities for local communities, and may generate or reinforce negative social consequences.

\section{Tourist Populations in Remote Areas}

Tourists visiting remote areas are typically thought of as people seeking experiences linked to nature and romantic notions such as unspoilt countryside, tranquillity or wilderness (Blomgren and Sørensen, 1998). However there are a range of different markets who visit remote destinations for a variety of reasons and motivations. Potential markets that remote regions have sought to capture in the past include travellers on organised sightseeing package tours (Schmallegger and Carson, 2010; Cerveny, 2008); special interest tourists (Harwood, 2008; Taylor and Prideaux, 2008); tourists visiting friends and relatives (Boyne, 2001); working holiday makers (Hanson and Bell, 2006); business visitors (Nash and Martin, 2003); transit travellers (Holyoak, Carson, and Schmallegger, 2009); second home owners (Hall and Müller, 2004), and long-term amenity migrants (Moss, 2006). Each of these is likely to seek different experiences and value different characteristics of the destination (Cohen, 1979).

\section{The Contribution of Tourists to Local Capital}

'Local capital' is used in this chapter as an overarching term that encompasses forms of economic, social and human capital. The impact of tourism development on the economic 
capital of a hosting community has been a common theme in the literature (Telfer, 2007). Proponents of tourism development typically over-emphasise contributions to economic capital, such as increases in foreign exchange, new infrastructure, employment, land value, and economic multiplier effects. In the context of remote tourism, however, researchers suggest the consideration of issues such as the nature and scale of investment in tourism infrastructure within a hosting community, local land and business ownership structures, or revenue leakages (Keller, 1987; Hall and Boyd, 2005). Understanding the impact of tourism and its contribution to human capital in remote communities is equally important. Human capital is essentially defined by the stock of skills, knowledge and human resources that are necessary to perform labour and create economic value (Thrane, 2008). Human capital is enhanced by education, training and experience and is a vital component of a community's capacity to make informed decisions and participate in tourism enterprises to maximise economic and social outcomes (Moscardo, 2008; Harwood, 2008).

Tourism can also have substantial impacts on the social fabric of hosting communities and the associated level and quality of social capital. Social capital refers to the social relations that emerge as a result of social norms, trust and reciprocity and can facilitate collective action for the sake of mutual benefits (Stone and Hughes, 2002). Social capital contributes to the vitality and internal cohesion of communities and describes the extent to which economic industries, such as tourism, are collectively embraced to reach common social and economic goals (Macbeth, Carson and Northcote, 2004). Changing labour structures, in-migration of external entrepreneurs and investors, or gentrification are some of the examples that the tourism literature identify as common impacts on social capital in hosting communities (George, Mair and Reid, 2009; Lundmark, 2005). The quality of social capital in a community is further influenced by political capital, indicating the level of community control over information and decision-making. Community engagement in planning and 
development decisions has often been described as critical for successful tourism development (Keller, 1987; Moscardo, 2008). The level of community engagement is substantially influenced by governance structures including provision for community input in decision making, such as the ability to decide on (or even reject) tourism as an economic development strategy (Harwood, 2008), the extent of a shared value system and land tenure arrangements.

To enable informed decisions about tourism development, remote communities need to understand the range of impacts that various tourist markets can have upon their local capital. The following section reports on the experiences made by remote communities in three different case study regions. The case studies include sightseeing tourism in Central Australia, fishing tourism as special interest tourism in southeast Alaska, and second home tourism in northern Sweden. The case studies provide a summary of the characteristics of their respective tourist markets and the impact that tourism development has had on local communities.

\section{Case Studies}

\section{Sightseeing Tourism in Central Australia}

Central Australia is a remote desert region located in the southern parts of Australia's

Northern Territory. It is a relatively sparsely populated region which comprises around 40 percent of the total Northern Territory landmass. With a population of about 30,000, Alice Springs is the main town and service centre for the region. While Alice Springs has a predominantly non-Aboriginal resident population, many of the smaller surrounding communities and settlements are almost exclusively Aboriginal. Due to the harsh climate and the relatively inhospitable desert environment the region's economy has only a very small primary resource sector and depends largely on public service industries and tourism. Leisure tourism in Central Australia dates back to the mid $20^{\text {th }}$ century when travel to the 
'Red Centre' with its iconic attractions Uluru (Ayers Rock), Kata Tjuta (the Olgas), and Watarrka (Kings Canyon) became popular. Images of these attractions have been extensively used in international marketing and have converted Central Australia into one of Australia's most iconic tourism destinations.

While the region recorded only a few thousand visitors in the early 1960s, visitor numbers grew dramatically in the following decades due to the increasing fame and promotion of Uluru and the 'Red Centre', improved transport and access infrastructure, and the growing number of organised sightseeing bus tours to the region. With the advent of organised charter flights in the 1980s, the region experienced a particularly strong increase in international visitor numbers. Over the past decade, about two thirds of visitors to UluruKata Tjuta National Park and almost half of all visitors to Alice Springs were international, with the main markets being the UK, Germany, other continental Europe, North America and Japan (Tourism Research Australia, 2009). Since the early 2000s, visitor numbers have started to decline again. In the most recent period 2006 to 2009, Central Australia was visited by around 450,000 leisure visitors per year.

The Central Australian visitor market is to a large extent comprised of what Carson (2007) called 'tick and flick' tourists. These tourists are mainly motivated by sightseeing and come to the region with the main purpose of visiting the key attractions in the area to tick them off their 'to-do-list'. They usually leave the region after a short period of time (i.e. after seeing the major sights) and proceed to the next destination on their itineraries. This market is characterised by extremely low repeat visitation and very short lengths of stay (Carson, 2007). Tourist itineraries in Central Australia typically include a standardised sightseeing tour of the Red Centre which comprises a three-day round trip from Alice Springs to Uluru, Watarrka and back to Alice Springs again (Carson and Taylor, 2006). Much of this tourist flow occurs on organised coach tours, but also independent travellers 
tend to follow similar itineraries because of a lack of alternative options (Schmallegger and Carson, 2010). Only few tourists stay longer than the average three-day trip and they usually do not engage in many activities other than sightseeing, bushwalking or wildlife viewing (Carson and Taylor, 2006).

The prominence of standard tour itineraries means that businesses are concentrated at the main tourist hubs Alice Springs, Kings Canyon, and Yulara (a purpose-built tourism resort town in the vicinity of Uluru). The tourism industry in these locations is structured to provide resort-type experiences which are dominated by a handful of large external companies. There are only very few local tourism businesses, particularly Aboriginal businesses, that have been able to survive in the marketplace over time (Carson and Taylor, 2006). For example, Yulara is run by a single externally based company, which provides various types of tourist services (e.g. accommodation, restaurants, day tours, souvenirs etc) in-house rather than outsourcing services to small local businesses. The dominance of such large external players and the focus on external mass markets has created a strong export mentality in the region where investment decisions are usually made in the interests of external financiers.

This approach is strongly supported by the Northern Territory government who has repeatedly made huge contributions to tourist infrastructure investment to make the region more attractive for external investors (Chlanda, 2004). Examples of major public tourism investment include big 'showy' infrastructure projects, such as the Yulara resort development, the construction of viewing platforms at Uluru, and the sealing of roads between Alice Springs, Uluru, and Kings Canyon. The government - keen to achieve a good return on investment and justify the large financial contributions made in the past keeps encouraging and promoting the same old mass tourism structures despite evidence of changing market needs and declining visitor numbers in recent years (Schmallegger and 
Carson, 2010). Instead of focusing on new markets and product development, the tourism industry in Central Australia appears to have become somewhat locked into a continuous mass tourism development path which does not encourage locally grown entrepreneurship and local economic benefits.

Apart from an identified lack of local tourism entrepreneurs, the region is characterised by a lack of local labour involved in tourism. Much of the required tourism labour is external and there are very high rates of staff turnover (Schmallegger and Carson, 2010). The tourism labour force is mainly comprised of seasonal or short-term employees who are attracted to Central Australia's remote resorts by higher monetary benefits or faster career advancement opportunities. For example, an overwhelming majority of Yulara's resort staff comes from outside the Northern Territory and has an average length of stay of not much more than a year (Chlanda, 2004). Residents of Yulara are primarily temporary, young to middle-aged employees of the resort and there are few other groups of residents, such as families, seniors or Aboriginal people, who could create a more cohesive social community environment.

As resort employees are expected to be external and temporary, the large tourism enterprises usually have limited ambitions to train staff locally. They rather seek to import reasonably skilled employees who are already trained in particular fields of operation. This has automatically limited opportunities for local employment, especially for Aboriginal people who do not qualify for these jobs. In the case of Yulara, not a single Aboriginal person from the neighbouring Aboriginal community of Mutitjulu was employed at the resort as per 2004 (Chlanda, 2004). Instead, the community is continuously battling with massive unemployment rates, social problems and outmigration. Local Aboriginal communities in Central Australia generally receive very little financial income from tourism, with the exception of some minor lease payments by businesses on Aboriginal land or 
entry fees to national parks that are under joint management agreements (Carson and Taylor, 2006). Despite ongoing promotion of Aboriginal tourism by the Northern Territory government, Aboriginal involvement in the tourism industry is still very limited in Central Australia (Carson and Taylor, 2006). Aboriginal communities, even if engaged in tourism, have only limited opportunities to influence decision-making in questions related to regional tourism development. The few Aboriginal tourism businesses that exist rely on external companies (and the government) to bring in visitors and are therefore extremely vulnerable to investment or marketing decisions made by these players.

\section{Fishing Tourism in Southeast Alaska}

The Alaska Panhandle, also known as 'Southeast Alaska', is a 1,000 km long archipelago of wooded islands and inland waterways along the Gulf of Alaska. The area is home to 70,300 residents, of which 45 percent live in Juneau. Another 32 formal settlements dot the coastline, with most only accessible by ferry or flight. Commercial fishing, prospecting, and logging have traditionally been the main engines of economic growth in the area. Since the mid $20^{\text {th }}$ century, tourism has become a critical component of the state's economic development effort (Dunning, 2000), with the development of cruise tourism being the main priority. Today, the vast majority (about 90 percent) of Southeast Alaska visitors are cruise ship passengers, primarily from North America, Europe, and Asia (Ringer, 2006). There is, however, a smaller portion of 'independent travellers' who fly into regional hubs, such as Juneau, Ketchikan, and Sitka, and then travel by ferry or float-plane to more isolated areas. These independent travellers have become important niche markets for remote towns. They are motivated by special interest activities, such as fishing (and to a lesser degree hunting), and the prospects of conducting these activities in a remote and untouched wilderness setting. 
Fishing tourists are an important market for remote areas in Alaska that are distant from the main cruise ship corridor. One example where fishing tourism has become a major industry is the remote township of Craig, located on the western coast of Prince of Wales Island. With a population of about 1,100 residents Craig is the island's largest town and is accessible from Ketchikan by air, ferry, or private marine vessel. Craig has traditionally been a fishing town, hosting year-round and transient fishers and cannery workers (Langdon, 1975), but also the timber industry used to be a main job provider on the island. Changes in fisheries management and market prices, as well as shifts in global timber supply, hit the community hard in the 1990s and more than 500 residents left the island between 1995 and 2000 (Gilbertsen and Robinson, 2001). A few former loggers and commercial fishermen decided to stay and try their hand at another industry: charter fishing.

Charter fishing tourism started in the 1980s when a group of investors purchased an historic cannery on the island and successfully converted it into a high-end fishing lodge. Inspired by the increasing demand for fishing experiences, new fishing charter operations were set up in nearby Craig. By the mid-1990s, there were seven charter boat operators working out of Craig who collaborated with local B\&B operators to provide packages of guided fishing tours, accommodation and meals. There was a subsequent gradual transition from charter boat to lodge based operations. As charter boat operators kept expanding, the logistics of coordinating external lodging and dining became burdensome and most operators opted to build a proper fishing lodge with a private dock (Cerveny, 2008). By 2001, twelve full-service fishing lodges operated in and around Craig. The number of registered charter boats on the island swelled from 32 in 1986 to 203 in 2000 and the number of annual fishing tourists visiting Craig increased to 6,000 (Alaska Commercial Fisheries Entry Commission, 2005). 
Charter fishing tourists typically fly in from Ketchikan by air taxi and spend an average of 3.5 days fishing. The majority of fishing guests are from the Northwest or Midwest regions of the US. They usually arrive in groups of friends or family members, who share a boat for the day. Some lodges cater to corporate groups from Seattle and Portland (Cerveny, 2005). A substantial number of fishing tourists in Craig (in some businesses up to 95 percent) are repeat visitors. They have often become attached both to individual lodges and to specific guides, and guests keep returning to the same lodges to fish with the same guides year after year (Cerveny, 2008). Fishing tourists mainly value the activity of fishing as a form of natural resource consumption. Important factors for them are 'tonnage' or the size of the fish and the volume of the total catch brought home. Fishing tourists are therefore in clear opposition to cruise tourists and other types of Alaska travellers who seek more 'passive' nature experiences.

Fishing tourism in Craig was initiated by private operators as opposed to public officials. Though island-wide entities endorsed tourism, Craig city officials, dominated by commercial fishing interests, were less keen to support the industry at first. Tour operators formed business groups which organised tourism planning and development and sponsored tourism workshops to spread trade information and provide hospitality training for the growing industry. Craig's tourism industry is very diverse and consists of a mix of local and external business operators. Fishing lodges are owned by a combination of longtime local residents, seasonal residents, and larger corporations, including one Seattle-based logging company and an Alaska Native corporation. The growth in fishing tourism also triggered growth in the general accommodation sector, including B\&Bs, rental cabins, and rooms for let. Most are small and family-run local operations designed to augment other sources of household income. 
Owing to its modest volume, fishing tourism has created relatively few social conflicts within the local community. In general, locals recognised economic benefits from tourism, such as new jobs or increased tax revenue. They were largely supportive of tourism so long as their little town would not end up like Craig's neighbour, Ketchikan, which in their eyes had been transformed from a real Alaska frontier town into an artificial mass tourism city (Cerveny, 2008 and 2005). However, locals did notice some of the drawbacks of the tourism industry which lead to tensions between different interest groups. For example, locals felt that lodge operators did not contribute as much to the local economy as they could. The lodge-based fishing format meant that the visitor experience was largely selfcontained, limiting opportunities for economic benefits to spread to other economic sectors. Lodge owners often spent some money locally on fuel, food or hardware but major supplies were usually purchased in Ketchikan, thus generating considerable economic leakage (Cerveny, 2008). Similarly, charter guests spent only minimally on local goods and services (e.g. on transportation, gifts, and food and beverages) as most of their expenses were included in the package price.

The growth of charter fishing created only a modest number of local jobs such as fish cleaners, cooks, waiters, and bartenders. These jobs were highly seasonal, low-paid and mostly taken up by students or women. Though it was recognised that young locals could learn important personal and professional skills through tourism, tourism jobs were generally perceived as only marginal and not for 'real Alaskans'. A substantial number of jobs (about 30 percent of all guiding jobs and 35 percent of all accommodation jobs) were held by non-residents (Hadland, 2004). Especially the larger lodges employed external seasonal workers, primarily as fishing guides (Gilbertsen and Robinson, 2001). The presence of external seasonal tourism employees caused some tensions among locals, as they were perceived to have different and conflicting interests, values, and lifestyles from 
long-term residents. Fishing guides, for example, were mostly young professionals with semi-nomadic fishing lifestyles who usually socialised among themselves and had only minimal interaction with long-term locals (Cerveny, 2008). In addition, they had strong social and economic ties outside Alaska, meaning that they left the region during off-season and spent their earnings elsewhere. Local commercial fishermen often felt displaced by the increasing charter industry. For them, the increasing visibility of lodge owners, tour operators, and guides in the community symbolised a shift away from their traditional industry and lifestyle, which left many long-term locals struggling while those involved in tourism (particularly seasonal residents with limited commitment to the community) appeared to be thriving.

\section{Second Home Tourism in Northern Sweden}

Large parts of the Nordic countryside have recently suffered from population loss caused by outmigration and demographic change (Lundholm and Malmberg, 2006; Amcoff and Westholm, 2007). This is particularly pertinent in peripheral areas (Pettersson, 2002). These areas are, however, populated to a far greater extent through certain seasons when second home owners and other tourists visit the countryside (Hall and Müller, 2004). The Finnish Islands Committee (Skärgårdsdelegationen, 2007) maintained that the permanent population in rural municipalities had decreased drastically over the past years, while the amount of second home owners had increased to a level which outnumbered the permanent population in many places.

Rural population loss cannot be explained by a fainting interest in rural life. Many second home owners are highly attached to the rural arena. They do not consider themselves as tourists but as (at least a seasonal) part of the community (Kaltenborn, 1997). Kaltenborn (1998) argued that second homes are indeed alternate homes rather than secondary shelters for tourists. Still, in most countries second home owners are not considered a part of the 
rural community. As outsiders they are deprived of fundamental citizen rights, such as election rights and participation in local planning, and they remain 'invisible' within administrative decision making (Müller and Hall, 2003).

In the more remote interior parts of northern Sweden, an area marked by almost constant outmigration, tourism development has long been advocated as a remedy to economic and social problems and indeed, many mountain villages are today dependent on tourism incomes (Müller and Ullrich, 2007). Second homes are an important contribution to tourism in the region. Due to their sheer number, almost abandoned villages are suddenly revitalized again during summer season and holiday periods. Still, the region qualifies mainly as an "extensively-used peripheral landscape" (Müller et al., 2004), implying a high share of second homes that are converted permanent homes and a long distance to demand markets. In larger parts of the area, however, second home tourism is rather regional (Müller, 2006). This means that second home tourists are recruited from urban areas along the Bothnian coast.

Second home owners differ significantly from permanent residents. While they are largely in the same age groups as their village neighbour (both permanent residents and second home owners are in the older age groups), second home owners are on average better educated and have higher disposable incomes. In many cases, second homes are inherited and carry considerable family heritage values for their owners. Many second home owners have a high degree of place attachment as a result of a intergenerational associations with the locale. They are loyal visitors and often not seen as tourist, but rather as 'absent villagers', who use their second homes for about two months of the year (Jansson and Müller, 2004).

An exception to this situation can be found in a number of alpine skiing resorts in the Swedish mountain range. Second homes in resort towns tend to attract higher numbers of 
long-haul visitors from the urban centres in southern Sweden (Lundmark and Marjavaara, 2005; Müller, 2005). In addition, purpose-built second homes tend to outnumber converted homes, and during recent years alpine resorts attracted considerable external investment from nearby Norway. Even though these homes are rented out occasionally during the winter season, they are only used half as often as other second homes in the area, which reduces their economic contribution to the local community substantially (Jansson and Müller, 2004).

The impact of second home tourism in the area was widely debated during the 1990s. Many municipal representatives claimed that second home owners consumed local services without contributing significantly to the local tax base. In addition, a specific shoreline protection program banned new constructions in most desirable locations. Today, the negative attitude towards second home tourism has changed significantly. Second homes are increasingly seized as a tool for regional development and the expenditure by second home owners on everyday supplies and building material is highly valued in the local community. Still, a problem for many remote villages is that the types of demands cannot be met by local supply. Population figures are already too low to support a retail store, even if the second home owners' demands are accredited. Thus the economic impact of second home tourism is mainly recorded in the municipal centres (Jansson and Müller, 2004). Second home tourism accounts for more than 10 percent of all tourism spending in Sweden, and means a lot to the local municipalities in rural and remote areas. Jansson and Müller (2004) estimated that about a third of second home households spend the equivalent of permanent resident households in interior municipalities in northern Sweden. However, the second home owners' expenses usually did not support any specific tourism companies or entail the establishment of new service supplies. Instead, it was mostly the 
existing shops and service suppliers who benefitted from second home tourism, as the demand of second home owners coincided with the needs of local residents.

Without the contribution of second home tourism some remote areas in northern Sweden would be what Müller (2004) has labelled 'disappearing regions'. Current debates on the future of peripheral areas in northern Sweden tend to overlook the economic impact of second home tourism on the social fabric of many communities and, thus, fail to grasp the complexities of change in remote communities. Second home owners need to be considered and integrated as an essential part of the more permanent resident community. However, easiness and continuity of current administrative practices are often favoured that portray rural and remote areas as abandoned.

\section{Towards a Remote Tourism Development Typology}

The three case studies have shown that catering to different tourist markets in remote areas leads to different forms of tourism development that impact on local communities in different ways. Table 1 summarises the three different 'remote tourism typologies' identified in the case studies.

Figure 1: A remote tourism development typology

\begin{tabular}{|c|c|c|c|}
\hline & $\begin{array}{l}\text { Sightseeing Tourism } \\
\text { (Tick \& Flick ) }\end{array}$ & $\begin{array}{l}\text { Special Interest Tourism } \\
\text { (Charter Fishing) }\end{array}$ & Second Home Tourism \\
\hline \multicolumn{4}{|c|}{ Market characteristics } \\
\hline Market size & - large numbers & - small numbers & - small - medium numbers \\
\hline Origin & - largely international & - largely domestic & $\begin{array}{l}\text { - largely domestic } \\
\text { - intra-regional market }\end{array}$ \\
\hline $\begin{array}{l}\text { Length of } \\
\text { stay }\end{array}$ & - very short & - short-medium & - long \\
\hline $\begin{array}{l}\text { Repeat } \\
\text { visitors }\end{array}$ & - no repeat visitors & - regular repeat visitors & - regular repeat visitors \\
\hline $\begin{array}{l}\text { Contact with } \\
\text { locals }\end{array}$ & - very limited & - medium & - very high \\
\hline $\begin{array}{l}\text { Experiences } \\
\text { sought }\end{array}$ & $\begin{array}{l}\text { - recreational - divisionary } \\
\text { - passive }\end{array}$ & $\begin{array}{l}\text { - recreational - divisionary } \\
\text { - } \text { active }\end{array}$ & - experimental - existential \\
\hline $\begin{array}{l}\text { Consumption } \\
\text { patterns }\end{array}$ & $\begin{array}{l}\text { - passive natural resource } \\
\text { consumption } \\
\text { - } \text { extractive - non- }\end{array}$ & $\begin{array}{l}\text { - active natural resource } \\
\text { consumption } \\
\text { - extractive - generative }\end{array}$ & $\begin{array}{l}\text { - } \text { equivalent to local } \\
\text { consumption } \\
\text { - } \text { non-extractive - } \\
\end{array}$ \\
\hline
\end{tabular}




\begin{tabular}{|c|c|c|c|}
\hline & generative & & generative \\
\hline \multicolumn{4}{|c|}{ Type of tourism development } \\
\hline $\begin{array}{l}\text { Size of } \\
\text { development }\end{array}$ & - large-scale & - small to medium scale & - small scale \\
\hline $\begin{array}{l}\text { Type of } \\
\text { infrastructure } \\
\text { investment }\end{array}$ & $\begin{array}{l}\text { tourism specific only - } \\
\text { not serving needs of } \\
\text { locals }\end{array}$ & $\begin{array}{l}\text { - serving mainly tourists } \\
\text { but also locals }\end{array}$ & $\begin{array}{l}\text { not tourism specific - } \\
\text { serving mainly local needs } \\
\text { - only few purpose built } \\
\text { second homes (in resort } \\
\text { towns) }\end{array}$ \\
\hline $\begin{array}{l}\text { Source of } \\
\text { investment }\end{array}$ & $\begin{array}{l}\text { - external investment } \\
\text { - strong public investment }\end{array}$ & $\begin{array}{l}\text { - both external and local } \\
\text { investment } \\
\text { - limited public investment }\end{array}$ & $\begin{array}{l}\text { - external and local } \\
\text { investment } \\
\text { - no public investment in } \\
\text { second home tourism }\end{array}$ \\
\hline $\begin{array}{l}\text { Product } \\
\text { structure }\end{array}$ & $\begin{array}{l}\text { - homogenous product } \\
\text { structure - no industry } \\
\text { diversity }\end{array}$ & $\begin{array}{l}\text { - fishing product is quite } \\
\text { homogenous } \\
\text { - but stimulates creation of } \\
\text { complementary products }\end{array}$ & $\begin{array}{l}\text { no significant new } \\
\text { product development for } \\
\text { second home owners } \\
\text { - } \text { products for locals }\end{array}$ \\
\hline \multicolumn{4}{|c|}{ Impact on local economic capital } \\
\hline $\begin{array}{l}\text { Ownership of } \\
\text { infrastructure }\end{array}$ & - external and government & - external and local & $\begin{array}{l}\text { - external (regional) and } \\
\text { local }\end{array}$ \\
\hline $\begin{array}{l}\text { Economic } \\
\text { linkages }\end{array}$ & $\begin{array}{l}\text { - creates very few linkages } \\
\text { to local operators }+ \\
\text { suppliers }\end{array}$ & $\begin{array}{l}\text { creates reasonable } \\
\text { linkages to local industry } \\
\text { - local linkages disappear } \\
\text { the larger operators } \\
\text { become }\end{array}$ & $\begin{array}{l}\text { - maintain strong linkages } \\
\text { to existing local industry } \\
\text { - do not create new } \\
\text { linkages }\end{array}$ \\
\hline $\begin{array}{l}\text { Revenue } \\
\text { leakage }\end{array}$ & $\begin{array}{l}\text { - large revenue leakage to } \\
\text { external operators }+ \\
\text { suppliers } \\
\text { - large revenue leakage } \\
\text { caused by seasonal } \\
\text { external workers }\end{array}$ & 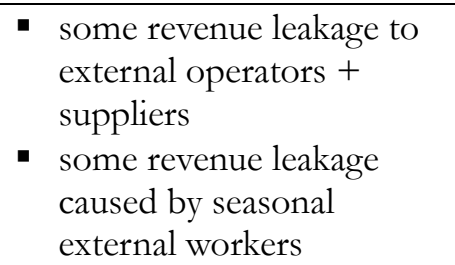 & $\begin{array}{l}\text { considerable revenue } \\
\text { leakage to municipal } \\
\text { centres when demand for } \\
\text { products can not be met } \\
\text { locally }\end{array}$ \\
\hline $\begin{array}{l}\text { Fiscal } \\
\text { linkages } \\
\text { (through } \\
\text { rents, taxes, } \\
\text { royalties) }\end{array}$ & $\begin{array}{l}\text { limited reinvestment of } \\
\text { rents and taxes into local } \\
\text { community - mainly into } \\
\text { new tourism } \\
\text { infrastructure }\end{array}$ & $\begin{array}{l}\text { - rents and taxes go mainly } \\
\text { back into community }\end{array}$ & $\begin{array}{l}\text { - high contribution to local } \\
\text { tax base } \\
\text { - tax revenue goes back into } \\
\text { community }\end{array}$ \\
\hline \multicolumn{4}{|c|}{ Impact on local human capital } \\
\hline Employment & $\begin{array}{l}\text { - mainly external labour } \\
\text { - very limited local } \\
\text { employment }\end{array}$ & $\begin{array}{l}\text { - imported labour for } \\
\text { specialised skills } \\
\text { - local employment } \\
\text { opportunities but mostly } \\
\text { seasonal or part-time jobs }\end{array}$ & $\begin{array}{l}\text { - helps maintain local } \\
\text { employment } \\
\text { - does not create extra jobs } \\
\text { in tourism }\end{array}$ \\
\hline $\begin{array}{l}\text { Capacity } \\
\text { building }\end{array}$ & $\begin{array}{l}\text { - very limited local capacity } \\
\text { building } \\
\text { - no need to train locals } \\
\text { because of imported } \\
\text { labour }\end{array}$ & $\begin{array}{l}\text { - some training and up- } \\
\text { skilling of locals in basic } \\
\text { business operations } \\
\text { - specialised skills are } \\
\text { imported and not built } \\
\text { locally }\end{array}$ & $\begin{array}{l}\text { no evident impact on } \\
\text { local capacity building in } \\
\text { tourism - second home } \\
\text { owners do not consume } \\
\text { specific tourism products }\end{array}$ \\
\hline Knowledge & $\begin{array}{l}\text { - imported knowledge only } \\
\text { - management/knowledge } \\
\text { positions are recruited }\end{array}$ & $\begin{array}{l}\text { imported knowledge } \\
\text { through external } \\
\text { operators and workers }\end{array}$ & $\begin{array}{l}\text { - no evident impact on } \\
\text { local knowledge } \\
\text { - does not require imported }\end{array}$ \\
\hline
\end{tabular}




\begin{tabular}{|c|c|c|c|}
\hline & $\begin{array}{l}\text { externally } \\
\text { - high knowledge leakage } \\
\text { when employees and } \\
\text { investors leave }\end{array}$ & $\begin{array}{l}\text { both locals and externals } \\
\text { in management positions } \\
\text { - some knowledge leakage } \\
\text { through seasonal } \\
\text { employment }\end{array}$ & $\begin{array}{l}\text { staff or knowledge for } \\
\text { tourism services }\end{array}$ \\
\hline $\begin{array}{l}\text { Local } \\
\text { entrepreneur- } \\
\text { ship }\end{array}$ & $\begin{array}{l}\text { - no stimulation of local } \\
\text { entrepreneurship }\end{array}$ & $\begin{array}{l}\text { - strong stimulation of } \\
\text { local entrepreneurship }\end{array}$ & $\begin{array}{l}\text { - no evident impact on } \\
\text { local entrepreneurship }\end{array}$ \\
\hline $\begin{array}{l}\text { Population } \\
\text { retention }\end{array}$ & $\begin{array}{l}\text { - } \begin{array}{l}\text { contributes to } \\
\text { outmigration }\end{array} \\
\end{array}$ & - helps retain locals in town & $\begin{array}{l}\text { - helps increase population } \\
\text { base }\end{array}$ \\
\hline \multicolumn{4}{|c|}{ Impact on local social capital } \\
\hline $\begin{array}{l}\text { Community } \\
\text { engagement }\end{array}$ & $\begin{array}{l}\text { - limited power in decision- } \\
\text { making for locals }\end{array}$ & $\begin{array}{l}\text { - locals are involved in } \\
\text { decision-making }\end{array}$ & $\begin{array}{l}\text { - locals are involved in } \\
\text { decision-making (but } \\
\text { second home owners } \\
\text { often excluded) }\end{array}$ \\
\hline $\begin{array}{l}\text { Community } \\
\text { support for } \\
\text { tourism }\end{array}$ & $\begin{array}{l}\text { - limited community } \\
\text { support for tourism }\end{array}$ & $\begin{array}{l}\text { - generally strong } \\
\text { community support (so } \\
\text { long as tourism stays } \\
\text { small) } \\
\text { - some resistance from } \\
\text { competing industry }\end{array}$ & $\begin{array}{l}\text { - no notable resistance } \\
\text { against second home } \\
\text { owners } \\
\text { - only some concerns } \\
\text { regarding building } \\
\text { restrictions }\end{array}$ \\
\hline $\begin{array}{l}\text { Social } \\
\text { cohesion }\end{array}$ & $\begin{array}{l}\text { - limited sense of } \\
\text { community due to social } \\
\text { and physical displacement } \\
\text { of locals }\end{array}$ & $\begin{array}{l}\text { - strong sense of } \\
\text { community - survival of } \\
\text { town is a common goal } \\
\text { - potential conflicts of } \\
\text { interest with other } \\
\text { industries }\end{array}$ & $\begin{array}{l}\text { - } \text { strong sense of } \\
\text { community } \\
\text { - second home owners feel } \\
\text { as part of community }\end{array}$ \\
\hline $\begin{array}{l}\text { Social } \\
\text { networks }\end{array}$ & $\begin{array}{l}\text { limited local networks } \\
\text { and alliances because of } \\
\text { external domination }\end{array}$ & $\begin{array}{l}\text { - formation of local } \\
\text { business networks and } \\
\text { interest groups }\end{array}$ & $\begin{array}{l}\text { no evident impact on } \\
\text { formation of social } \\
\text { networks } \\
\text { - second home owners } \\
\text { likely to integrate with } \\
\text { existing social networks }\end{array}$ \\
\hline
\end{tabular}

'Tick and flick' sightseeing tourism is likely to result in high-volume international markets

that are characterised by very short lengths of stay, extremely low repeat visitation, and very

limited contact with local communities. They consume local natural resources for

recreational and divisionary purposes (albeit in a passive way) and are highly 'extractive' in

nature, meaning that they consume local resources with little contribution to the local

community. Tourism development is based on large-scale infrastructure that is created for

tourism purposes only as opposed to local needs. It is largely financed, and consequently

owned, by external investors and dependent on support from government agencies.

Product structures tend to become very homogenous over time as demand is shaped and 
coordinated by external operators and the highly organised time schedules of tourists do not leave room for alternative complementary products. The contribution of 'tick and flick' tourism to local economic capital is limited as externally owned businesses create very few local economic linkages and cause high rates of revenue leakage. Similarly, its contribution to local human capital development is limited because it does not emphasise local employment or build local capacity in tourism, as knowledge and staff tend to be externally sourced. The almost stifling dominance of external operators does not encourage local entrepreneurship and instead tends to alienate locals. Negative effects on local social capital are obvious. Locals have very limited power in decision-making and are often not supportive of tourism.

Charter fishing as a form of special interest tourism is almost the opposite. The market is largely domestic and characterised by small numbers, short to medium lengths of stay, and high repeat visitation. Visitors look for recreational and divisionary experiences which are 'extractive' to the extent that they consume local natural resources (i.e. fish). At the same time, their behaviour is 'generative' because the charter fishing contributes substantially to local capital. Tourism development in Craig has primarily been small-scale in nature. There has been a mix of local and external investment and a clear lack of public sector investment, indicating a healthy and competitive local business environment. In its early stages, the charter industry created considerable economic linkages within the local industry by cooperating with local accommodation or meal providers. However, as operators became bigger, they were likely to dissolve these linkages again. Although lodge operators contributed to local tax revenue and purchased some local supplies, there were significant levels of revenue leakage, particularly where fishing lodges were owned by external operators. Fishing tourism did create local jobs, but most of these jobs were associated with low-esteem seasonal and part-time jobs for women and students. There was some 
basic local capacity building through learning-by-doing and more formal training seminars. However, specialised skills and knowledge (for example for guiding) were externally sourced rather than built internally. Nevertheless, the development of charter fishing has lead to an increased number of local entrepreneurs and has helped retain locals in town that may have otherwise left. Locals are largely in control of decision-making and generally supportive of fishing tourism. However, it should not be ignored that tourism has also caused some tensions in the community, particularly among commercial fishermen who felt that tourism threatened traditional lifestyles and industries.

Second home owners in northern Sweden represent what Cohen (1979) has described as experimental or existential types of tourist. They have a very high emotional attachment to their remote community and choose to live, at least temporarily, as part of the community and adopt local behaviour. Although absolute numbers of second home owners in northern Sweden are still low, in some communities they have outnumbered permanent residents during high seasons. Second home owners are largely domestic and include a considerable intra-regional market. They usually stay for a long time, are regular repeat visitors and integrate with permanent residents on a regular basis. Their consumption patterns are equivalent to those of locals and are therefore non-extractive and generative. Apart from their second homes, they do not require much in terms of specialised tourism products or infrastructure so that tourism development as such remains relatively small and locally owned. Economic leakage mainly occurs when second home owners buy supplies in bigger regional centres because the local stores can not meet their demands. There is no public investment to stimulate further second home tourism development, although municipalities nowadays do appreciate second home owners because of contributions to the local tax base. Second home owners do not necessarily create new economic linkages in the local industry or stimulate extra employment in classic tourism jobs. However, they do 
use existing service providers, which in turn strengthens the local industry and maintains local employment. As second home tourism remains small-scale and 'invisible', locals have usually been supportive, mostly because second home owners tend to integrate with community life. There are hardly any conflicts over excessive infrastructure development or tourist behaviour and locals have largely remained in control of decision-making.

\section{Conclusion}

This chapter identified three different types of tourist markets to remote regions with respect to their contributions to local capital. Information derived from this analysis highlights the various impacts that tourism can have upon local communities. These impacts were described as ranging from merely extractive, whereby the attributes of the locale are consumed without deference to future or current local population requirements, to generative impacts that suggest that some markets invest back into the locale and ensure its ongoing survival. Accessing information on the impacts of various types of development enables local communities the ability to make informed decisions that utilise their tourist populations in ways that create and foster local capital to ensure viability.

\section{References}

Alaska Commercial Fisheries Entry Commission (2005) Registered Charter Fishing Vessels: Prince of Wales Island. Data on file with author.

Amcoff, J. and Westholm, E. (2007). Understanding rural change: demography as a key to the future.

Blomgren, K., and Sørensen, A. (1998). Peripherality - Factor or Feature? Reflections on Peripherality in Tourism Research. Progress in Tourism and Hospitality Research, 4, 319336.

Boyne, S. (2001). VFR (Visiting Friends and Relatives) Tourism in Rural Scotland: A Geographical Case Study Analysis. In J. Lennon (ed.) Tourism Statistics: International 
Perspectives and Current Issues. London: Continuum.

Bradbury, J.H. and St-Martin, I. (1983). Winding Down in a Quebec Mining Town: A case study of Schefferville. Canadian Geographer, 27(2), 128-144.

Carson, D. (2007). The declining value of icon attractions in the Northern Territory: Lessons for regional Australia. Paper presented at the 2007 Symposium 'Cross collaboration in hospitality and related services: Synergies and future possibilities', 26 October 2007, Cairns: Centre for Tropical Tourism and Hospitality, James Cook University.

Carson, D., and Taylor, A. (2006). Finding the way: Visit patterns and industrial organisation around the Red Centre Way, 2000 - 2005. Darwin: Tourism Research Group, Charles Darwin University.

Cerveny, L.K. (2008). Nature and tourists in the Last Frontier: Local encounters with global tourism in coastal Alaska. Elmsford, New York: Cognizant Communications.

Cerveny, L.K. (2005). Tourism and its effects on Southeast Alaska communities and resources: Case studies from Haines, Craig, and Hoonah, Alaska. Research Paper, PNW-RP-566. Portland, OR: USDA Forest Service, Pacific Northwest Research Station.

Chlanda, E. (2004, December 01). Twenty years on: Looking back over resort's rocky road. Alice Springs News, 1144. Retrieved June 05, 2009, from: http://www.alicespringsnews.com.au/1144.html

Cohen, E. (1979). A Phenomenology of Tourist Experiences. Sociology, 13(2), 179-201.

Dunning, M. (2000). Tourism in Ketchikan and southeast Alaska. Alaska History, 15(2), 31 43.

George, E. W., Mair, H., and Reid, D. G. (2009). Rural Tourism Development: Localism and Cultural Change. Bristol: Channel View Publications.

Gilbertsen, N. and Robinson, D. (2001). Prince of Wales Island. Alaska Economic Trends, 21(11), 3-8. 
Hadland, J. (2004). Nonresidents working in Alaska-2002. Alaska Economic Trends, 24(2), 321.

Hall, C. M. and Boyd, S. (2005). Nature-based Tourism in Peripheral Areas: Introduction. In C. M. Hall and S. Boyd (eds.), Nature-based Tourism in Peripheral Areas: Development or Disaster? (pp. 3-17). Clevedon: Channel View Publications.

Hall, C.M. and Müller, D.K. (Eds.) (2004). Tourism, Mobility and Second Homes: Between Elite Landscapes and Common Ground. Clevedon: Channel View.

Halseth, G. and Sullivan, L. (2003). The Bright Lights of the City: Intra-Regional Migration and the Challenge for Resource-Dependent Towns. Geography Research Forum, 23, 138168.

Hanson, J. and Bell, M. (2006). Harvest trails in Australia: Patterns of seasonal migration in the fruit and vegetable industry. Journal of Rural Studies, 23(1), 101-117.

Harwood, S. (2008). Planning and development of community based tourism: Bird watching destinations. In S. Richardson, L. Fredline, A. Patiar and M. Ternel (eds.), Proceedings of the 18 $8^{\text {th }}$ Annual CAUTHE Conference, 11-14 February. Griffith University: Gold Coast.

Holyoak, N., Carson, D. and Schmallegger, D. (2009) 'VRUMTM: A tool for modelling travel patterns of self-drive tourists', in A. Frew, U. Gretzel and W. Hoepken (eds.) Information and Communication Technologies in Tourism 2009, Wien - New York: Springer.

Jansson, B. and D.K. Müller (2004): Second home plans among second home owners in northern Europe's periphery. In C.M. Hall and D.K. Müller (eds.) Mobility, Tourism and Second Homes: Between Elite Landscape and Common Ground. Clevedon: Channel View, pp. 261-272.

Kaltenborn, B. P. (1997). Nature of place attachment: study among recreation home owners in southern Norway. Leisure Sciences 19, 175-189. 
Kaltenborn, B. P. (1998). The alternate home: motives of recreation home use. Norsk Geografisk Tidsskrift 51, 187-198.

Keller, C. P. (1987). Stages of Peripheral Tourism Development: Canada's Northwest Territories. Tourism Management, 8, 20-32.

Langdon, S. J. (1975). A social and educational history of Craig. Cambridge, MA: Abt Publications.

Lundholm, E. and Malmberg, G. (2006). Gains and losses, outcomes of interregional migration in the five Nordic countries. Geografiska Annaler B8(1), 35-48.

Lundmark, L. and Marjavaara, R. (2005). Second home localizations in the Swedish mountain range. Tourism 53 (1) pp. 3-16.

Lundmark, L., 2005: Economic Restructuring into Tourism in the Swedish Mountain Range. Scandinavian Journal of Hospitality and Tourism 5(1), 23-45.

Macbeth, J., Carson, D. and Northcote, J. (2004). Social Capital, Tourism and Regional Development: SPCC as a Basis for Innovation and Sustainability. Current Issues in Tourism, 7(6), 502-522.

Moscardo, G. (2008). Community Capacity Building: an Emerging Challenge for Tourism Development. In G. Moscardo (ed.), Building Community Capacity for Tourism Development (pp. 1-15). Oxfordshire: Cab International.

Moss, L. A. G. (2006). The Amenity Migrants: Ecological Challenge to Contemporary Shangri-La. In L. A. G. Moss (ed.), The Amenity Migrants: Seeking and Sustaining Mountains and their Cultures (pp. 3-25). Oxfordshire: Cab International.

Müller D.K. (2004): Second homes in Sweden: patterns and issues. In C.M. Hall and D.K. Müller (eds.) Tourism, Mobility and Second Homes: Between Elite Landscape and Common Ground. Clevedon: Channel View, pp. 244-258.

Müller D.K., C.M. Hall and D. Keen (2004): Second home tourism impact, planning and 
management. In C.M. Hall and D.K. Müller (eds.) Tourism, Mobility and Second Homes: Between Elite Landscape and Common Ground. Clevedon: Channel View, pp. 15-32.

Müller, D.K. and Hall, C.M. (2003). Second homes and regional population distribution: on administrative practices and failures in Sweden. Espace, Populations, Societies 2003(2), 251-261.

Müller, D.K. and Ullrich, P. (2007). Tourism development and the rural labor market in Sweden, 1960-1999. In D.K. Müller and B. Jansson (eds.) Tourism in Peripheries: Perspectives from the Far North and South. Wallingford: CABI, pp. 85-104.

Müller, D.K. (2005). Second home tourism in the Swedish mountain range. In C.M. Hall and S. Boyd (eds.) Nature-based Tourism in Peripheral Areas: Development or Disaster? Clevedon: Channel View, pp. 133-148.

Müller, D.K. (2006). The attractiveness of second home areas in Sweden: a quantitative analysis. Current Issues in Tourism 8(4and5), 335-350.

Nash, R., and Martin, A. (2003). Tourism in Peripheral Areas: The Challenges for Northeast Scotland. International Journal of Tourism Research, 5, 161-181.

Pettersson, Ö. (2002). Socio-Economic Dynamics in Sparse Regional Structures. Umeå: Kulturgeografiska institutionen.

Randall, J.E. and Ironside, R.G. (1996). Communities on the Edge: An economic geography of resource-dependent communities in Canada. Canadian Geographer, 40(1), $17-35$.

Ringer, G. (2006). Cruising North to Alaska: The new gold rush. In R. Dowling (Ed.), Cruise tourism: Issues, impacts, cases. (pp. Oxford: CABI Publishing.

Schmallegger, D. and Carson, D. (2010). Is Tourism Just Another Staple? A new perspective on tourism in remote regions. Current Issues in Tourism, in press.

Skärgårdsdelegationen (2007). Finland: Öarnas och sjöarnas land. Helsinki: 
Inrikesdepartementet.

Stone,W. and Hughes, J. (2002) Social Capital. Empirical meaning and measurement validity, 27: Australian Institute of Family Studies. www.aifs.org.au/institute/pubs/RP27.pdf. Taylor, A. and Prideaux, B. (2008). Profiling four wheel drive tourism markets for desert Australia. Journal of Vacation Marketing, 14(1): 71-86.

Telfer, D. (2007). The Evolution of Tourism and Development Theory. In R. Sharpley and D. Telfer (eds.), Tourism and Development: Concepts and Issues (pp. 38-80). Clevedon: Channel View Publications.

Thrane, C. (2008). Earnings differentiation in the tourism industry: Gender, human capital and socio-demographic effects. Tourism Management, 29(3), 514-524.

Tourism Research Australia (2009). National and International Visitor Data, CD Mota online. Retrieved 18 July, 2009, from http://traonline.australia.com.

Williams, A.M. and Hall, C.M. (2000). Tourism and Migration: new relationships between production and consumption. Tourism Geographies, 2(1), 5-27. 